\title{
Ortaokul Öğrencilerinin Zihinden Hesaplama Yaparken Kullandıkları Stratejiler
}

\section{The Strategies Used by Middle School Students to Make Mental Computation}

\author{
Murat Duran, Matematik Öğretmeni, Amasya Suluova Atatürk Ortaokulu,denizyildizi2805@hotmail.com \\ Muhammet Doruk, Araştırma Görevlisi, Atatürk Üniversitesi Kazım Karabekir Eğitim Fakültesi, İlköğretim \\ Matematik Öğretmenliği Anabilim Dall, mdoruk20@gmail.com \\ Abdullah Kaplan, Prof. Dr., Atatürk Üniversitesi Kazım Karabekir Eğitim Fakültesi, İlköğretim Matematik \\ Öğretmenliği Anabilim Dalı, akaplan@atauni.edu.tr
}

\begin{abstract}
ÖZ. Bu araștırmanın amacı ortaokul beșinci sınıf öğrencilerinin toplama-çıkarma işlemi yaparken kullandıkları ve tercih ettikleri ideal zihinden hesaplama stratejilerini belirlemektir. Nitel araştırma modellerinden özel durum çalışmasına göre desenlenen bu araştırma, 2014-2015 öğretim yllının güz döneminde gerçekleştirilmiştir. Araştırma, bir devlet ortaokulunda öğrenim gören 16'sı erkek 17'si kız olmak üzere toplam 33 beşinci sınıf öğrencisiyle gerçekleștirilmiştir. Araştırmanın verileri araştırmacılar tarafından geliştirilmiş etkinlik temelli yarı yapılandırılmış görüşme formu ile toplanmıștır. Görüşme formundan elde edilen veriler mevcut zihinden toplama ve çıkarma yapma stratejilerine göre betimsel olarak çözümlenmiştir. Araştırmadan elde edilen sonuçlara göre toplama işleminde öğrencilerin en fazla "onluklara ve birliklere ayırarak ekleme" stratejisini, en az ise "sayıları onu referans alarak parçalama" stratejisini kullandıkları belirlenmiştir. Çıkarma işleminde ise öğrencilerin en fazla "onar onar eksiltme" stratejisini, en az ise "onlukları ve birlikleri ayırarak çıkarma" stratejisini kullandıkları tespit edilmiştir. Buna rağmen çoğu öğrencinin zihinden toplama ve çıkarma işlemlerine yönelik herhangi bir stratejiyi doğru şekilde kullanmadığı ya da bu sorulara cevap vermediği belirlenmiștir. Öğrencilerin tercih edilen zihinden hesaplamaları değerlendirmeleri incelendiğinde, büyük oranda kullandıkları stratejiler yönünde tercihte bulundukları tespit edilmiştir.
\end{abstract}

Anahtar Kelimeler. Zihinden Hesaplama, Strateji, Ortaokul Öğrencileri, Matematik Eğitimi

\begin{abstract}
The purpose of this research is to determine mental computation strategies used to make additionsubtraction by fifth grade students. Also, the students' choices for the ideal mental computation strategies are examined in this research. The research designed according to case study of qualitative research models was carried out in the fall semester of 2014-2015 academic terms. The research was conducted with 33 fifth grade students, including 16 boys and 17 girls, studying in a state middle school. The research data were collected with a task based semi-structured interview protocol developed by researchers. Qualitative data obtained from the interview protocol were examined by descriptive analysis according to existing mental computation strategies of addition-subtraction. According to the results of the research students used at most "Adding by dividing into decimal and unity" and at least "Dividing based ten" in addition. Also, students used at most "Subtracting ten by ten" and at least "Subtracting by dividing into decimal and unity" in subtraction. Nevertheless, most students did not use any strategy for addition-subtraction and answer the questions correctly. When the students' assessments for the favoured mental computation strategies examined, the students preferred the strategies that they use substantially.
\end{abstract}

Keywords. Mental Computation, Strategy, Middle School Students, Mathematics Education

\section{SUMMARY}

Purpose and Significance: Mental computation is a concept closely related to the individuals who have responsibility in almost all levels of society. Students learn better relationships between numbers and see the numbers what features they have on transactions through mental computation. The strategy of mental computation is a concept which allows students to use the number of combinations that sense and benefit from the relationship between numbers. Individuals use the strategies of mental computation informal way, mostly faced profit-loss calculation in the field of trade. The purpose of this research is to determine the strategies of mental computation preferred and used to make addition-subtraction by fifth grade students.

Methodology: A specific case study of qualitative research models is used in this study. The research is conducted with 33 fifth grade students studying in a state middle school. The average age of these 
students is 12 . The research is carried out in the fall semester of 2014-2015 academic terms. Typical situation sampling of purposeful sampling method is used for determining the participants of the study. Data collection tool for this study is an activity based semi-structured interview protocol developed by the researchers to determine the strategies of mental computation used and preferred in addition-subtraction by middle school students. While there are five open-ended questions about used mental computation strategies in the first part of interview protocol, there are two open-ended questions about preferred mental computation strategies in the second part of interview protocol. All qualitative data obtained from the answers given the questions in the interview protocol examined by descriptive analysis.

Results: When the answers given to the first and second open-ended questions were evaluated together students used at most "Adding by dividing into decimal and unity", then "Adding on" and at least "Dividing based ten" in addition. When the answers given the third open-ended question were examined students used at most "Starting easy collected numbers", then "Subtracting by dividing into decimal and unity" and at least "Adding on". Nevertheless, most students did not use any strategy for addition and answer the questions correctly. Similarly, when the answers given to the fourth and fifth open-ended questions were evaluated together students used at most "Subtracting ten by ten" and at least "Subtracting by dividing into decimal and unity". Most students did not use any strategy for subtraction and answer the questions correctly as in addition. Students preferred at most "Adding on" in addition and at least "Subtracting ten by ten" in subtraction.

Discussion and Conclusions: Making the classroom activities to increase the number sense of students in mathematics courses may enhance more usage of the strategies of mental computation because of the close relationship between mental computation and number sense. Thus, students can exhibit less behaviours both using calculator and counting with fingers. Using decisive to faster, more convenient and practical strategies of mental computation increase achievement in mathematics courses. Therefore, new learning environments developed new strategies of mental computation should be provided to students by teachers.

\section{GÍRIS}

Günümüzde bir eğitim programının kalitesi öğrenme ortamlarında yetiștirilen bireylerin bilgiye ne ölçüde sahip oldukları, bilgiyi günlük hayatta ne düzeyde kullanabildikleri ve bilimi ne kadar yönlendirdikleriyle ölçülmektedir. Bu sayede nitelikli bir eğitim programından günlük hayatta ortaya çıkan problemleri farklı stratejiler kullanarak çözmeyi başaran insanlar yetiştirmesi beklenir (Yazgan \& Bintaş, 2005). Matematik öğretim sürecinde seçilen stratejiler öğretim programlarında yer alan hedef ve davranışların gerçekleştirilmesinde önemli bir unsurdur (Pesen, 2004). Öğretim programları için önemli görülen stratejilere günlük hayatta kullanılan hesaplama yöntemleri örnek gösterilebilir. Bu hesaplama yöntemleri yazılı hesap, tahmini hesap, zihinden hesap ve hesap makinesi yoluyla yapılan hesap olmak üzere dörde ayrılır (Van de Walle, 1994). Bu hesap türleri arasında kabul edilen zihinden hesaplama bireylerin bilgisayar, hesap makinesi ya da kâğıt-kalem gibi araçlar kullanmadan sadece zihinsel olarak yerine getirdikleri aktiviteler olarak tanımlanır (Trafton, 1978). Yani zihinsel hesaplamada sayılar arasındaki ilişkiler ve işlem özellikleri kullanılarak hesaplamalar gerçekleştirilir (Ceylan \& Özdemir, 2012). Zihinden hesaplama sayılar dünyasında hızlı ve esnek şekilde hareket etme şeklinde de nitelendirilir (Buys, 2008). Zihinden hesaplama, sayıların yapısının ve temel özelliklerinin daha iyi anlaşılmasını teşvik eder (Reys, 1984). Sayıların taşınma yollarını ustaca öğrenmeleri noktasında bireyleri cesaretlendiren zihinden hesaplama, problem çözme becerisi kazanmaya katkı sağlar (Reys, 1984).

Zihinden hesaplama toplumun hemen her kademesinde sorumluluk sahibi olan bireyleri yakından ilgilendirmektedir (Rubenstein, 2001). Örneğin bir futbolcunun kaç maçı daha kazanırsa şampiyon olacağını belirlemede, seyahat halindeki bir şoförün kalan süreyi belirlemesinde ve bir memurun yapılan zam sonrası yeni maaşını belirlemede zihinden hesaplamalara başvurulabilir. Bireyler daha çok ticaret alanında karşılaştıkları kâr-zarar hesaplamalarında kendilerince geliştirdikleri zihinden hesaplama stratejilerini informal yollardan kullanmaktadır (Carraher, Carraher \& Schliemann, 1985; Çavuş Erdem \& Duran, 2015). Hatta günlük hayatta alım-satım 
işleriyle meşgul olan bireylerin oranlama-karşılaştırma problemlerinde farklı çözüm yolları tercih ederek farklı stratejiler ürettikleri ve bu konuda akranlarına göre daha başarılı oldukları bilinmektedir (Saxe, 1988). Zihinden hesaplamayla birlikte öğrenciler sayılar arasındaki ilişkileri daha iyi kavramakta ve sayıların işlemlerde hangi özelliklere sahip olduklarını görmektedir (Reys, 1985; Akt. Sowder, 1990). Öğrenciler zihinden hesaplama yaparken şekli, içgüdüsel ve ihtiyaçlar sonucunda doğal olarak gerçekleșen stratejilerden yararlanırlar (Ceylan \& Özdemir, 2012). Öğrencilerin anlamlandırdıkları sayı kombinasyonlarını kullanmalarına ve bu sayılar arasındaki ilişkilerden yararlanmalarına olanak veren (Van de Walle, Karp \& Bay-Williams, 2014) bu stratejiler "zihinden hesaplama stratejileri" șeklinde belirtilir.

Sayı duygusunun gelişmesinde (Wyatt, 1985), öğrenmenin kolaylaştırılmasında (Rubenstein, 2001) ve temel bilgilerin çağrılmasında (Sowder, 1988) önemli olan zihinden hesaplama stratejileri bu özelliklerinden dolayı uluslararası öğretim programlarında odak noktası haline gelmiştir (Reys \& Barger, 1994; Reys, Reys, Nohda \& Emori, 1995; Treffers \& de Moor, 1990; Willis, 1990). Matematik Öğretmenleri Ulusal Konseyi (NCTM) belirlediği standartlarda öğrencilerin zihinden hesaplama stratejilerine yönelik kavrayışlarını ve kullanımlarını değerlendirerek iyi problem çözücü olma noktasında öğretmenlerin öğrencilere yardımcı olması gerektiğini açıklamıştır (NCTM, 2000). Benzer şekilde İngiltere'deki ulusal öğretim programında matematik eğitiminin temel amaçları arasında zihinsel hesaplama becerilerinin geliştirilmesi söz konusudur (Department of Education and Science, 1987; National Curriculum for England, 1999). Hollanda'daki matematik öğretim programlarında zihinden toplama ve çıkarma işlemine yönelik davranışların yazılı hesaplamaya yönelik davranışlardan daha önce kazandırılması gereğinden bahsedilmiştir (Beishuizen, 1993; Heirdsfield, 2002). Avustralya'da zihinden hesaplama becerilerine hâkim olmak çok önemli bir yeteneğe sahip olmak șeklinde değerlendirilmektedir (Australian Education Council, 1991).

Ülkemizde de Milli Eğitim Bakanlığı (MEB), günlük yaşamdaki ihtiyaçları karşılamak için ortaokul matematik öğretim programında öğrencilerin tahminde bulunma ve zihinden işlem yapma becerilerini etkin şekilde kullanmalarını sağlayan kazanımlara yer vermiștir (MEB, 2009). MEB'in belirlediği ortaokul matematik ders kitaplarında zihinden toplama stratejileri "onluklara ve birliklere ayırarak ekleme, üzerine sayma, sayıları 10'u referans alarak parçalama, kolay toplanan sayılardan başlama" olmak üzere dört ana başlık altında sunulurken zihinden çıkarma stratejileri "onlukları ve birlikleri ayırarak çıkarma, onar onar eksiltme" başlıkları altında açıklanmıştır (MEB, 2014). Daha sonra ortaokul matematik ders kitaplarını revize eden MEB, dört başlık altında topladığı zihinden toplama stratejileriyle iki başlık altında topladığı zihinden çıkarma stratejilerine yeni stratejiler eklemiştir (MEB, 2015). Zihinden toplama stratejilerine eklenen strateji "en yakın onluğa yuvarlayıp topla, farkı çıkar" şeklinde isimlendirilirken zihinden çıkarma stratejilerine eklenen stratejiler "çıkarılana benzet, çıkar/topla" ve "en yakın onluğa yuvarlayıp çıkar, farkı topla" şeklinde belirtilmiștir. MEB'in $(2014,2015)$ ortaokul beșinci sınıf ders kitaplarında yer alan zihinden toplama ve çıkarma stratejilerinin eski-yeni isimleri ile bu stratejilere yönelik örnekler Tablo 1'de gösterilmiştir. 
Tablo 1. Toplama ve Çıkarma İşlemlerine Yönelik Zihinden Hesaplama Stratejileri

\begin{tabular}{|c|c|c|c|}
\hline $\begin{array}{c}\text { Zihinden } \\
\text { Toplama/Çıkarma } \\
\text { Stratejileri Eski İsim } \\
\text { (MEB, 2014) }\end{array}$ & $\begin{array}{c}\text { Zihinden } \\
\text { Toplama/Çıkarma } \\
\text { Stratejileri Yeni } \\
\text { İsim (MEB, 2015) }\end{array}$ & $\begin{array}{l}\text { Zihinden Toplama } \\
\text { Örnekleri } \\
27+24 / 27+24+13\end{array}$ & $\begin{array}{l}\text { Zihinden Çıkarma } \\
\text { Örneği } \\
34-22\end{array}$ \\
\hline $\begin{array}{c}\text { Onluklara ve } \\
\text { Birliklere Ayırarak } \\
\text { Ekleme/Onlukları ve } \\
\text { Birlikleri Ayırarak } \\
\text { Çıkarmak }\end{array}$ & $\begin{array}{c}\text { Onları Topla, } \\
\text { Birleri Topla, } \\
\text { Birleştir/ Onlukları } \\
\text { ve Birlikleri } \\
\text { Ayırarak Çıkarmak }\end{array}$ & $\begin{array}{c}27+20=47 ; 47+4=51 \\
27+4=31 ; 31+20=51 \\
20+20=40 ; 7+4=11 ; \\
40+11=51 \\
20+20=40 ; 40+7=47 \\
47+4=51\end{array}$ & $\begin{array}{c}34-20=14 ; 14-2=12 \\
34-2=32 ; 32-20=12 \\
30-20=10 ; 4-2=2 ; 10+2=12\end{array}$ \\
\hline $\begin{array}{l}\text { Üzerine Sayma/Onar } \\
\text { Onar Eksiltme }\end{array}$ & $\begin{array}{l}\text { Onları Topla, } \\
\text { Birleri Topla/Onar } \\
\text { Onar Çıkarmak }\end{array}$ & $\begin{array}{c}27+10=37 ; 37+10=47 \\
47+4=51\end{array}$ & $\begin{array}{c}34-10=24 ; 24-10=14 ; 14- \\
2=12\end{array}$ \\
\hline $\begin{array}{l}\text { Sayıları Onu Referans } \\
\text { Alarak Parçalama/--- }\end{array}$ & $\begin{array}{c}\text { Onu Referans } \\
\text { Alarak Parçala/--- }\end{array}$ & $\begin{array}{l}27+3=30 ; 30+21=51 \\
6+24=30 ; 21+30=51\end{array}$ & --- \\
\hline $\begin{array}{c}\text { Kolay Toplanan } \\
\text { Sayılardan Başlama/-- } \\
-\end{array}$ & $---/--$ & $27+13=40 ; 40+24=64$ & --- \\
\hline ---/--- & $\begin{array}{c}\text { En Yakın Onluğa } \\
\text { Yuvarlayıp Topla, } \\
\text { Farkı Çıkar/--- }\end{array}$ & $\begin{array}{l}30+24=54 ; 54-3=51 \\
27+30=57 ; 57-6=51\end{array}$ & --- \\
\hline ---/--- & $\begin{array}{c}\text {---/Çıkarılana } \\
\text { Benzet, Çıkar-Topla }\end{array}$ & --- & $32-22=10 ; 10+2=12$ \\
\hline$---/--$ & $\begin{array}{l}\text {---/En Yakın } \\
\text { Onluğa Yuvarlayıp } \\
\text { Çıkar, Farkı Topla }\end{array}$ & --- & $34-30=4 ; 4+8=12$ \\
\hline
\end{tabular}

Zihinden hesaplamayla ilgili bir araştırmada ders kitaplarıyla öğretim yapan bazı öğretmenlerin, zihinden hesaplama stratejilerinin nasıl kullanıldığını atlayarak önce toplama ve çarpma kavramlarını verdikleri ardından bu kuralların ezberlenmesini istedikleri görülmüștür (Van de Walle vd., 2014). Başka bir araştırmada ise toplama ve çarpma gibi temel kuralların ezber yoluyla öğretimi sonunda öğrencilerin alıştırmalar üzerinde kuralları yanlış uyguladıkları, esnek stratejileri öğrenemedikleri ve sayı sayma yöntemini kullanmaya devam ettikleri gözlenmiştir (Baroody, 2006). Temel kural stratejilerinin ezberlenmesine destek veren ders kitaplarını kullanan öğrencilerin sayı hissi yeterliklerinin daha düșük olduğu da bilinmektedir (Henry \& Brown, 2008). Yukarıda belirtilen olumsuz durumlar bu araștırmanın yapılmasındaki birinci gerekçedir. Nitekim bireylere zihinden hesaplama stratejilerini seçme konusunda firsatlar tanıyarak onları bu noktada serbest bırakmak bireyleri sayma yapmadan kısa zamanda daha doğru sonuca ulaştıracaktır (Heirdsfield, 2001).

İlkokul düzeyindeki öğrencilerle yapılan nicel ve nitel araştırmalarda bu öğrencilerin toplama ve çıkarmaya yönelik problem çözerken kullandıkları zihinden hesaplama stratejileri, yanlış kullanılan stratejilerdeki hatalara yönelik düşünceleri, zihinden hesaplama yetenekleri ve bu yeteneklerin sayı hissi kavramıyla olan ilișkileri incelenmiștir (Beishuizen, 1993; Carraher, et al., 1987; Cooper, Heirdsfield \& Irons, 1995; Heirdsfield, 2002; Heirdsfield \& Cooper, 2004a, 2004b; McIntosh \& Dole, 2000; Morais \& Serrazina, 2013; Reys et al., 1995). Bu çalışmalardan elde edilen 
sonuçlarda ilkokul öğrencilerinin zihinden hesaplama konusunda yetersiz oldukları ve farklı stratejiler yardımıyla çözüme ulaşmada başarısız oldukları görülmüştür. Bu çalışmalara katılan öğrencilerin karşılaştıkları problemlerde sınırlı sayıda zihinden hesaplama stratejisi kullandıkları görülmüştür. Zihinden hesaplama stratejisini kullanan öğrenciler toplama ve çıkarma işlemlerinin sonuçlarını zihinlerinde canlandırdıkları bir kâğıt üzerinde kalemle işlem yapıyormuş gibi davranışlar sergilemiştir (Cooper et al., 1995). Bu çalışmalardan elde edilen diğer bir ortak sonuç ise öğrencilerin "kâğıt-kalem algoritmasının zihinsel imgesi" başlıklı stratejiye odaklanarak problemleri daha doğru çözmeleri olmuştur (McIntosh \& Dole, 2000; Reys et al., 1995). Bunun dişında nicel araştırma yöntemleriyle yapılan araştırmalarda zihinden hesaplama kavramı ile sayı hissi kavramı arasındaki yüksek düzeyde anlamlı bir ilişki olduğu vurgulanmıștır (Heirdsfield, 2001). Buna göre zihinden hesaplamadaki zayıflığın yeterince sayı duygusuna sahip olmamaktan kaynaklandığı ifade edilmiştir (Heirdsfield, 2002).

Literatürde zihinden hesaplama stratejilerine yönelik çalışmalar incelendiğinde çoğu çalışmanın ilkokul öğrencileri üzerinde gerçekleştirildiği görülecektir. Ayrıca bu çalışmalarda kullanılan zihinden hesaplama stratejilerinin Beishuizen (1993) ile Heirdsfield ve Cooper'ın (2004a, 2004b) araştırmalarında kullanılan "soldan sağa, sağdan sola, ilk toplanan rakam, ikinci toplanan rakam, yığılmalı toplamlar, dengeleme, düzleştirme, yeniden gruplama, kâğıt-kalem algoritmasının zihinsel imgesi" isimli stratejilerle sınırlandığı tespit edilmiștir. Bu durum bu araştırmanın yapılmasındaki ikinci gerekçedir. Nitekim yapılan bu çalışma, literatürdeki çalışmalardan farklı olarak sadece ortaokul öğrencileri düzeyine indirgenmiștir. Ayrıca bu çalıșmada literatürde yer alan zihinden hesaplama stratejilerinin dışında MEB (2014) tarafından ortaokul 5.sınıf matematik ders kitaplarındaki "üzerine sayma, kolay toplanan sayılardan başlama, onar onar eksiltme" stratejileri de kullanılacaktır. Bu durumda araştırmadan elde edilecek sonuçların zihinden hesaplama ve mental aritmetik üzerine çalışan matematik eğitimi araştırmacılarına ışı tutacağı düşünülmektedir. Buradan hareketle bu araştırmanın amacı ortaokul beşinci sınıf öğrencilerinin zihinden hesaplama yaparken kullandıkları ve tercih ettikleri zihinden hesaplama stratejilerini belirlemektir. Araştırmanın genel amacına uygun olarak aşağıdaki alt problemlere cevap aranmıştır:

1- Öğrencilerin zihinden toplama işlemi yaparken kullandıkları ve tercih ettikleri ideal stratejiler nelerdir?

2- Öğrencilerin zihinden çıkarma işlemi yaparken kullandıkları ve tercih ettikleri ideal stratejiler nelerdir?

\section{Araştırma Deseni}

\section{YÖNTEM}

Araştırmada ortaokul beşinci sınıf öğrencilerinin toplama ve çıkarma işlemleri yaparken kullandıkları zihinden hesaplama stratejileri belirlenmeye çalıșılmıştır. Bunun yanı sıra, öğrencilerin tercih edilen toplama-çıkarma işlemlerini değerlendirmeleri incelenerek, zihinden toplama-çıkarma işlemleri yaparken kullanılan hesaplama stratejileri ile tercih edilen zihinden hesaplama stratejileri arasındaki ilișkiler ortaya çıkarılması amaçlanmıștır. $\mathrm{Bu}$ nedenle çalışmada nitel araştırma modellerinden özel durum çalışması (case study) kullanılmıștır. Nitel araştırmalar; gözlem, görüşme ve doküman analizi gibi nitel veri toplama araçlarının kullanıldığı, olgu ve olayların doğal ortamında gerçekçi bir biçimde ortaya konmasına yönelik süreci izleyen araştırmalardır (Yıldırım \& Şimşek, 2008). Durum çalışmaları ise bütünsel bir betimleme odağında araştırılacak kurumun, grubun, programın vs. ortak paydalarının tespit edildiği çalışmalardır (Merriam, 2013; Stake, 2005; Akt. Glesne, 2013).

\section{Çalışma Grubu}

$\mathrm{Bu}$ araştırma, bir devlet ortaokulun beșinci sınıfında öğrenim gören 33 beşinci sınıf öğrencisinin katılımıyla gerçekleștirilmiștir. Bu öğrencilerin yaş ortalamaları 12'dir. Araştırma 20142015 eğitim-öğretim yılının güz döneminde yapılmıştır. Araştırma grubu belirlenirken amaçlı örnekleme yöntemlerinden tipik durum örneklemesi kullanılmıştır. Tipik durum örneklemesinde normal ve ortalama durumlar hakkında bilgi edinmek amaçlanır (Glesne, 2013). Araştırmada 
ortaokul beșinci sınıf öğrencilerinin tercih edilmesinin sebebi, bu öğrencilerin matematik dersinde zihinden toplama ve çıkarma işlemi stratejileri konusunun öğretiminin henüz yapılmış olmasıdır. Dolayısıyla araștırma grubunu oluşturan öğrencilerin zihinden toplama ve çıkarma işleminde kullanılan stratejilere yönelik bilgi sahibi oldukları söylenebilir. Ayrıca, 12 yaş ve üzeri bireyler, somut işlemler dönemindeki bireylere oranla daha analitik düşünmekte ve problem çözümleri için daha farklı hipotezler kurmaktadır (Piaget, 1976). Bu nedenle soyut işlemler dönemindeki beşinci sınıf öğrencilerinin toplama ve çıkarma işlemi yaparken kullandıkları zihinden hesaplama stratejileri daha net belirlenebileceği düşünülmüştür. Öğrencilere zihinden hesaplama stratejilerinin öğretimi birinci yazar tarafından gerçekleștirilmiștir.

\section{Veri Toplama Aracı}

$\mathrm{Bu}$ araştırmanın veri toplama aracı, ortaokul öğrencilerinin toplama-çıkarma işleminde kullandıkları ve tercih ettikleri zihinden hesaplama stratejilerini belirlemek amacıyla araștırmacılar tarafından geliștirilmiş yarı yapılandırılmış görüșme formudur (Ek 1). Yarı yapılandırılmış görüşmeler, tam yapılandırılmış görüşmeler kadar katı olmayan, yapılandırılmamış görüşmeler kadar da esnek olmayan iki uç arasındaki görüşme türleridir (Karasar, 2005). 2014-2015 öğretim yılında kullanılan ortaokul beşinci sınıf matematik ders kitabı referans alınarak (MEB, 2014) soruları oluşturulan taslak haldeki yarı yapılandırılmış görüşme formunda iki bölüm bulunmaktadır. Birinci bölümde öğrencilerin toplama işlemi yaparken kullandıkları zihinden hesaplama stratejilerine yönelik üç açık uçlu soru ile çıkarma işlemi yaparken kullandıkları zihinden hesaplama stratejilerine yönelik iki açık uçlu soru olmak üzere toplam beş açık uçlu soru yer almaktadır. İkinci bölümde ise toplama işlemine yönelik sorulan bir soru ve bu soru altında tercih edilebilecek dört farklı zihinden hesaplama stratejilerine yönelik çözümler bulunmaktadır. Ayrıca aynı bölümde çıkarma işlemine yönelik bir soru ve bu soru altında tercih edilebilecek iki farklı zihinden hesaplama stratejilerine yönelik çözümler yer almaktadır. Bu sorular ile öğrencilerin kullanılan stratejileri değerlendirerek hangi stratejileri tercih edeceklerini ortaya çıkarmak amaçlanmıștır.

\section{Verilerin Toplanması}

Görüşme formundaki sorulara yönelik pilot uygulama öncesinde MEB'in 5.sınıf kazanımlarında yer alan "iki basamaklı doğal sayılarla zihinden toplama ve çıkarma işlemlerinde uygun stratejiyi seçerek kullanır" kazanımı esas alınarak bir öğretim gerçekleştirilmiştir. Bu öğretim sürecinde bu çalışmada kullanılacak olan bütün stratejiler hakkında öğrencilere bilgi verilmiștir. Bilgi verildikten sonra öğrencilerle etkinlikler yapılmış ve bu etkinlikler sonunda öğrenciler konuyu anladıklarını belirtmiştir. Pilot uygulama öncesinde zihinden hesaplama alanında çalışma yapmış bir öğretim üyesi ile iki matematik öğretmeni olmak üzere toplam üç uzmanın görüşlerine başvurulmuştur. Formun kapsam geçerliğini belirlemek için soruların literatürde tanımlı olan zihinden hesaplama stratejilerini temsil edip etmediği uzmanlara sorulmuştur. Bunun yanı sıra formdaki bölümlerin açık, net ve anlaşılır olup olmadığına, soruların zorluk düzeylerine ve formun ölçme amacına hizmet edip etmediğine yönelik uzmanlardan bilgi alınmıştır. Uygulanacak taslak görüşme formunun öğrenci seviyesine uygunluğunu belirlemek, uygulamanın ortalama süresini tespit etmek ve görüşme sırasında ortaya çıkabilecek sorunları gidermek amacıyla üç ortaokul beşinci sınıf öğrencisiyle pilot uygulama yapılmıştır. Pilot uygulama sonunda görüşme formuna verilen cevaplar uzmanlar tarafından tekrar gözden geçirilmiştir. Uzmanlar taslak görüşme formunun ikinci bölümündeki toplama işlemine yönelik tercih edilebilecek zihinden hesaplama stratejilerinden "kolay toplanan sayılardan başlama" stratejisinin soru köküyle uyumsuz olduğu gerekçesiyle çıkarılmasını istemiştir. Bu sayede toplama işlemine yönelik tercih edilebilecek "kolay toplanan sayılardan başlama" zihinden hesaplama stratejisi o sorudan çıarılmıştır. Tüm bu işlemlerden sonra taslak halindeki yarı yapılandırılmış görüşme formuna son hali verilmiştir.

Görüşme formunun nihai uygulaması yapılmadan önce ilgili kurumdan resmi izinler alınmış ve kurumdaki diğer yöneticiler de uygulama hakkında bilgilendirilmiştir. Nihai uygulama öncesi öğrencilere; görüşmelerin hiçbir şekilde matematik ders notuna etki etmeyeceği, katılacak 
öğrencilerin kimliklerinin gizleneceği, katılımın isteğe bağlı olduğu ve bu uygulamanın sadece bir araştırmada kullanılacağı belirtilmiştir. Nihai uygulama birinci yazar tarafından 2014-2015 öğretim yılı güz döneminde bir devlet ortaokulunun beșinci sınıfında öğrenim gören 33 öğrenciye ders saatleri dışındaki bir öğle arasında yapılmıştır. Uygulamanın sakin bir ortamda gerçekleștirilmesi hedeflendiğinden öğle arası tercih edilmiştir. Nihai uygulamada araştırmacı öğrencilere herhangi bir süre baskısında bulunmamıştır. Buna rağmen her bir görüşme ortalama 15 dakika sürmüştür.

Görüşme formundaki sorular öğrencilere aynı sıra ile sorulmuştur. Öğrencilere ilk olarak, zihinden toplama ve çıkarma sorularını sıra ile yapmaları istenmiştir. Bu sorularda öğrencilerin kullandıkları stratejilere odaklanılmıştır. İkinci bölümde öğrencilere toplama ve çıkarma işlemi ile ilgili birer soru için farklı stratejiler kullanılarak yapılan hesaplamalar yazılı olarak sunulmuştur. Öğrencilerden bu hesaplamalardan hangisini tercih edecekleri sorulmuştur. Bu bölümdeki etkinlikler yardımıyla öğrencilerin tercih ettikleri stratejiler hakkında bilgi elde etmek amaçlanmıştır. Ayrıca iki bölüm birbiri ile karşılaştırılarak öğrencilerin gerçekte kullandıkları stratejiler ile tercih ettikleri stratejiler arasında bir ilişkinin olup olmadığı ortaya çıkarılacaktır. Çalışmada kullanılan bu yöntem aynı zamanda bir veri çeşitlemesidir. Veri çeşitleme süreci bir temayı veya bir perspektifi aydınlatmak için farklı kaynaklardan destekleyici kanıtları kapsamaktadır. Bu sayede bulgular geçerlik kazanmaktadır (Creswell, 2013). Nihai uygulama tüm öğrenciler için hedeflenen bir buçuk haftada tamamlanmıştır. Nihai uygulamaya katılan her bir öğrenci için $\ddot{O}_{1}, \ddot{O}_{2}, \ldots \ddot{O}_{33}$ şeklinde kodlar verilerek öğrencilerin kimlikleri gizlenmiştir. Görüşmeler yapılırken her öğrenciden sesli şekilde toplama-çıkarma işlemlerini yapmaları ve anlattıkları bu işlemleri devamında zaman kaybetmeden kâğıda dökmeleri istenmiştir. Böylece toplama-çıkarma işlemleri yaparken kullandıkları ve tercih ettikleri zihinden hesaplama stratejileri belirlenmeye çalışılmıștır. Bu sayede öğrencilerin yaptıkları çözümler üzerinde hiçbir değișiklik yapmadan sunmak ve dolayısıyla çalışmanın inandırıcılığını arttırmak hedeflenmiştir. Yapılan görüşmelerin tamamı ses kayıt cihazıyla kaydedilmiştir. Daha sonra bu kayıtlar araștırmacılar tarafından transkript edilmiștir. Transkriptler sonunda öğrenci cevapları ses kayıt cihazından tekrar dinlenmiştir. Transkriptlerden öğrencilerin sesli düşünerek yaptıkları zihinden hesaplamaların cevap kağıdına doğru bir şekilde yansıtılıp yansıtılmadığı kontrol edilmiştir. Çalışmada öğrencilerin yaptıkları çözümler sıklıkla betimsel olarak sunulmuş, bu sayede çalışma bulgularının geçerliğinin ve güvenirliğinin arttırılması hedeflenmiştir.

\section{Verilerin Analizi}

$\mathrm{Bu}$ araştırmada görüşme formundan elde edilen verilerin tümü betimsel analiz yaklaşımıyla ele alınmıştır. Verilerin analizine temel oluşturan kodlar önceden belirlendiği için araştırmada betimsel analiz yöntemi kullanılmıștır (Yıldırım \& Şimşek, 2008). Betimsel analiz, verilerin açık ve sistematik bir biçimde betimlendiği, yapılan betimlemelerin açılanıp yorumlandığı ve neden-sonuç ilişkilerinin irdelendiği analiz yöntemidir (Yıldırım \& Şimşek, 2008). Ayrıca bu yöntemi kullanarak ulaşılan sonuçlar temalar bakımından ilişkilendirilir, anlamlandırılır ve geleceğe yönelik kestirimlerde bulunulur (Yıldırım \& Şimşek, 2008). Bu araştırmada öncelikle öğrencilerin cevap kâğıtları kategorize edilmek suretiyle görüşme formuna verilen cevaplardan elde edilen veriler "zihinden toplama işlemi yaparken kullanılan stratejiler", "zihinden toplama işleminde tercih edilen stratejiler", "zihinden çıkarma işlemi yaparken kullanılan stratejiler" ve "zihinden çıkarma işleminde tercih edilen stratejiler" ana temaları altında düzenlenmiştir. Bu temalar çerçevesinde elde edilen veriler ortak temaların tespiti açısından anlamlı biçimde bir araya getirilerek (Creswell, 2013) ana tema ve alt temalara göre tekrar edilme sıklıklarına bağlı olarak frekans tablolarıyla gösterilmiştir. Öğrenci cevaplarından doğrudan alıntılarla desteklenen veriler yorumlanmıştır. Çalışmadan elde edilen bulgular hem kendi içerisinde hem de literatürle tartışılarak açılanmaya çalıșılmıștır.

\section{Çalışmanın Geçerliği ve Güvenirliği}

Nitel bir araştırmanın literatürde kabul görebilmesi için inandırıcılık, aktarılabilirlik, tutarlılık ve teyit edilebilirlik özelliklerini sağlaması gerekir (Lincoln \& Guba, 1985). Buna göre araştırmanın inandırıcılığını arttırmak amacıyla yarı yapılandırılmış görüşme formu hazırlanırken 
kuramsal yapı dikkate alınmış, ses kayıt cihazı yardımıyla elde edilen veriler yazılı hale dönüştürüldükten sonra iki araştırmacı tarafından ayrı ayrı kontrol edilmiştir. Veri toplama süreci açık ve net bir şekilde okuyucuya anlatılmıș, bulgular bölümündeki katılımcı cevapları değiştirilmeden doğrudan okuyucuya sunulmuştur. Veriler analiz edildikten sonra iki katılımcıyla tekrardan görüşme yapılmış ve bulgulara ilişkin katılımcı teyidi sağlanmıştır. Bunun dışında görüşmenin yapılacağı ortamın sessiz olmasına dikkat edilerek görüşmenin sağlıklı geçmesi sağlanmıştır. Araştırmanın aktarılabilirliğini arttırmak amacıyla araştırmanın yöntemi, çalışma grubu, veri toplama aracı, verilerin toplanması, analizi ve yorumlanması ayrıntılı bir șekilde okuyucuya anlatılmıştır. Ayrıca araştırmaya katılan öğrencilere kimlikleri belli olmayacak şekilde kodlar verilmiştir. Araştırmanın tutarlılığını arttırmak amacıyla öğrencilerle yapılan görüşmelere yönelik kodlamalar iki araştırmacı tarafından ayrı ayrı yapılmıştır. Bu kodlamalar daha sonra karşılaştırılmış ve Miles ve Huberman'ın (1994) güvenirliği hesaplama formülüne göre uyum yüzdesi görüşme formunun genelinde .94 hesaplanmıştır. Araştırmanın teyit edilebilirliğini arttırmak amacıyla araştırmadan elde edilen verilerden mümkün olduğunca ve yeterli sayıda alıntı kullanılmıştır. Ayrıca araştırmada ortaya çıkan veriler tekrar incelenme ihtimaline karşı araştırmacılar tarafından saklanmıştır.

\section{BULGULAR}

Araştırmanın bu bölümünde öğrencilerin zihinden toplama-çıkarma işlemi yaparken kullandıkları stratejiler ve yapılan zihinden toplama-çıkarma işlemleri için tercih ettikleri stratejiler hakkında elde edilen bulgular sunulmuştur. Öğrencilerin kullandıkları stratejiler ile yapılan hesaplamalara yönelik tercih edilen stratejileri karşılaştırabilmek için söz konusu bulgular birbiri ardına sunulmuştur.

\section{Zihinden Toplama İşlemi Yaparken Kullanılan Stratejiler}

Öğrencilerin zihinden toplama işlemi yaparken kullandıkları stratejileri ortaya çıkarabilmek için öğrencilere farklı özellikteki üç adet toplama işlemini yapmaları istenmiştir $(43+28,37+32$, $14+21+26)$. Öğrencilerin hem yazılı hem de sözlü ifadeleri dikkate alınarak kullandıkları stratejiler tespit edilmeye çalışılmıştır. Öğrencilerin zihinden toplama işlemi yaparken kullandıkları stratejilerin beş kategori altında toplandığı belirlenmiştir. Bu kategoriler; onluklara ve birliklere ayırarak ekleme, üzerine sayma, sayıları onu referans alarak parçalama, kolay toplanan sayılardan başlama ve strateji yok veya boş kategorileridir. Tablo 2'de öğrencilerin zihinden toplama işlemi yaparken kullandıkları stratejiler hakkında bilgiler sunulmuştur.

Tablo 2. Zihinden Toplama İșlemi Yaparken Kullanılan Stratejiler

\begin{tabular}{lcccccccc}
\hline \multicolumn{1}{c}{ Stratejiler } & 1.Soru & $\%$ & 2.Soru & $\%$ & 3.Soru & $\%$ & TOPLAM & $\%$ \\
\hline Onluklara ve birliklere ayırarak ekleme & 11 & 33 & 9 & 27 & 3 & 9 & 23 & 23 \\
Üzerine sayma & 8 & 24 & 10 & 30 & 1 & 3 & 19 & 19 \\
Sayıları onu referans alarak parçalama & 1 & 3 & 2 & 6 & - & - & 3 & 3 \\
Kolay toplanan sayılardan başlama & - & - & - & - & 7 & 21 & 7 & 7 \\
Strateji yok veya boș & 13 & 39 & 12 & 36 & 22 & 67 & 47 & 47 \\
TOPLAM & 33 & 100 & 33 & 100 & 33 & 100 & 99 & 100 \\
\hline
\end{tabular}

Tablo 2'ye göre öğrencilerin kullandıkları zihinden toplama stratejileri incelendiğinde, en çok "onluklara ve birliklere ayırarak ekleme" stratejisini daha sonra da "üzerine sayma" stratejisini kullandıkları görülmüştür. Öğrencilerin çok az bir kısmının ise "sayıları onu referans alarak parçalama" stratejisini kullandıkları tespit edilmiştir. Ayrıca çoğu öğrencinin zihinden toplama işlemine yönelik herhangi bir stratejiye sahip olmadığı belirlenmiştir. Buna göre öğrencilerin çoğunun zihinden toplama stratejileriyle ilgili bilgi düzeylerinin yeterli olmadığı ya da bu stratejilerden herhangi birini de olsa özümsemedikleri söylenebilir. 
Tablo 2'deki bulgular genel olarak değerlendirildiğinde, öğrencilerin zihinden toplama işlemi yapma girişimlerinin yaklaşık yarısında (\%47) herhangi bir strateji uygulayamadıkları veya boş bıraktıkları görülmüștür. Buna göre, öğrencilerin zihinden toplama işlemi yaparken güçlük yaşadıkları söylenebilir. Bu durumun çalışmada öğrencilere sorulan her üç soru için de değişmediği ortaya çıkmıştır. Öğrencilerin \%39'u birinci soruda, \%36'sı ikinci soruda ve \%67'si de üçüncü soruda bu kategoriye ait cevaplar vermiştir. Bu bulgulardan hareketle öğrencilerin en çok üçlü toplama işleminin yapıldığı üçüncü soruda güçlük yaşadıkları ve uygun bir strateji kullanamadıkları tespit edilmiştir. Buna göre öğrencilerin en çok üç tane iki basamaklı sayıyı zihinden toplarken sıkıntı çektikleri söylenebilir. Bu kategorideki öğrencilere örnek olması açısından Ö ${ }_{19}$ kodlu öğrencinin birinci soruya yönelik zihinden toplama işlemi için verdiği yanıt Şekil 1'de sunulmuştur.

Şekil 1. Herhangi Bir Zihinden Toplama Stratejisinin Kullanılmadı̆̆ı Çözüm

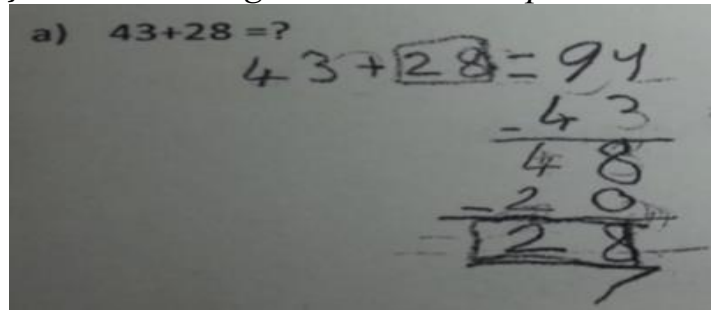

Şekil 1'e göre Ö$_{19}$ kodlu öğrenci birinci sorunun çözümü için herhangi bir strateji kullanamamış ve soruyu yanlış çözmüştür. Öğrenci toplanacak iki sayıdan herhangi birisini onluklara ve birliklere parçalamadan ya da üzerine sayma stratejisine imkân verecek şekilde sayıları onar onar ayırmadan birbirleriyle doğrudan toplamıș ve sonucu yanlıș bulmuştur. Daha sonra öğrenci sonucun doğru olup olmadığını teyit etmek için işlemlerin sağlamasını yapmaya çalışmıș ve yaptığı işlemlerin "toplama ve çıkarma stratejisi" adı altında olduğunu iddia etmiştir. Buna göre Ö ${ }_{19}$ kodlu öğrencinin zihinden toplama ve çıkarma stratejilerine yönelik bilgilerinde eksikliklerin olduğu söylenebilir.

Zihinden toplama işlemine yönelik uygun stratejiler kullanan öğrenciler arasında en çok kullanılan stratejilerin "Onluklara ve birliklere ayırarak ekleme" ve "Üzerine sayma" stratejileri olduğu ortaya çıkmıștır. Bu iki strateji arasından en çok tercih edilen ise, az bir fark ile "Onluklara ve birliklere ayırarak ekleme" stratejisi olduğu tespit edilmiştir (\%23). Bu strateji en çok birinci soru için kullanılmıştır (\%33). İkinci ve üçüncü sorular için ikinci sırada kullanılan strateji olmuştur. Şekil 2'de birinci soru için bu stratejiyi kullanan $\mathrm{Ö}_{11}$ kodlu öğrencinin yanıtı örnek olarak sunulmuştur.

Şekil 2. Onluklara ve Birliklere Ayırarak Ekleme Stratejisinin Kullanıldığı Çözüm

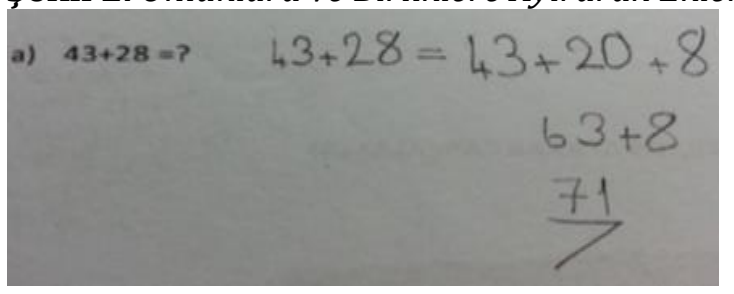

Şekil 2'ye göre Ö ${ }_{11}$ kodlu öğrenci kullandığı stratejide toplanan sayılardan 28 sayısını, 20 ve 8 sayılarının toplamı şeklinde yazarak sayıyı bir tane onluğa ve bir tane birliğe ayırmıştır. Daha sonra toplanacak olan 43 sayısıyla daha önce onluğa ve birliğe ayırdığı sayıları ikili ikili toplamış ve 71 sonucuna ulaşmıştır.

Onluklara ve birliklere ayırarak ekleme stratejisi ile birlikte en çok kullanılan strateji üzerine sayma stratejisi olmuştur (\%19). Bu stratejinin ikinci soruda en çok kullanılan strateji olduğu tesit edilmiştir. Şekil 3’te ikinci soru için üzerine sayma stratejisini kullanan Ö$_{13}$ kodlu öğrencinin verdiği yanıt örnek olarak sunulmuştur.

Şekil 3. Üzerine Sayma Stratejisinin Kullanıldı̆̆ı Çözüm 


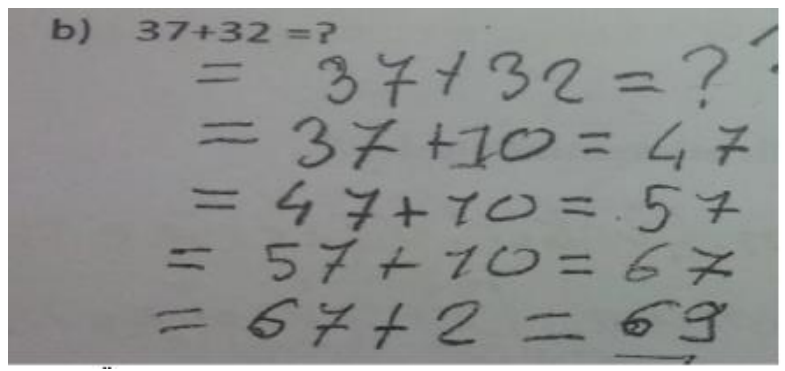

Şekil 3'e göre $\ddot{O ̈}_{13}$ kodlu öğrenci kullandığı stratejide toplanan sayılardan 32 sayısını ayırabildiği kadar onluğa ayırıp geriye de bir tane birliği temsil eden 2 sayısı kalacak şekilde sayıları toplanmak üzere yazmıştır. Daha sonra üzerinde herhangi bir işlem yapılmayan ve sabit bekleyen 37 sayısını da onluklarla ve birlikle ikili ikili toplayarak 69 sonucuna ulaşmıştır.

Öğrencilerin çok az bir kısmı zihinden toplama işlemi yaparken "kolay toplanan sayılardan başlama" ve "Sayıları onu referans alarak parçalama" stratejilerini kullanmıștır. Sayıları onu referans alarak parçalama stratejisi en az kullanılan strateji olmuştur (\%3). Bu yöntem üçlü toplamanın olduğu üçüncü soruda hiç kullanılmamıștır. İkili toplamlar için uygun olmayan kolay toplanan sayılardan başlama yöntemi ise, beklenildiği gibi ikili toplamın olduğu birinci ve ikinci soruda kullanılmamıştır. Üçlü toplama işleminin yapıldığı üçüncü soruda ise öğrenciler tarafından çok az kullanıldığı belirlenmiştir (\%7). Üçüncü soruda da kullanılma sıklığına göre "onluklara ve birliklere ayırarak ekleme" ve "üzerine sayma" stratejilerine göre geri planda kalmıștır. Bu stratejiyi kullanan Ö5 kodlu öğrencinin çözümü Şekil 4'te sunulmuştur.

Şekil 4. Kolay Toplanan Sayılardan Başlama Stratejisinin Kullanıldığı Çözüm

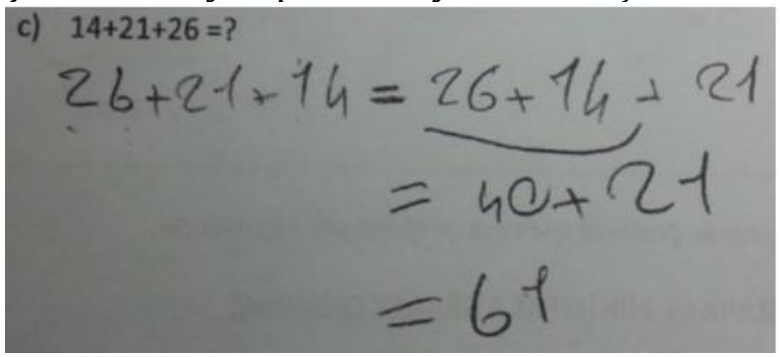

Şekil 4'e göre Ö 5 kodlu öğrenci kullandığı stratejide toplama işleminin birleşme özelliğinden yararlanmıștır. Burada öğrenci toplamının sonucu 10'un katını verecek şekilde 26 ve 14 sayılarını topladıktan sonra geriye kalan 21 sayısını onluklarına ve birliklerine parçalamadan daha önceki toplamdan gelen 40 sayısıyla toplamış ve 61 sonucuna ulaşmıştır.

\section{Zihinden Toplama İşlemi Yaparken Tercih Edilen Stratejiler}

Öğrencilerin yapılan zihinden toplama işlemlerinde kullandıkları stratejileri değerlendirmeleri istenmiştir. Öğrencilere ikili toplama işlemine yönelik "Onluklara ve birliklere ayırarak ekleme", " Üzerine sayma" ve "Sayıları onu referans alarak parçalama" stratejilerine göre yapılmış üç çözüm yazılı olarak sunulmuş ve hangi yöntemi tercih ettikleri sorulmuştur. Çalışmada kullanılan bu değerlendirme etkinliği ile veri çeşitlemesi yaparak öğrencilerin gerçekten benimsedikleri zihinden toplama stratejisini ortaya çıkarmaktır. Aksi takdirde, öğrencilerin kullandıkları ile tercih ettikleri stratejiler arasında farklılığın olması durumunda da ortaya çıkan bu farklılığının nedenlerini araştırmak hedeflenmiştir. Öğrencilerin yapılan zihinden toplama işlemi için tercih ettikleri stratejilerin dağılımı hakkındaki bilgilere Tablo 3 'te yer verilmiștir. 
Tablo 3. Zihinden Toplama İșleminde Tercih Edilen Stratejiler

\begin{tabular}{lccc}
\hline Stratejiler & $\begin{array}{c}\text { Onluklara ve } \\
\text { Birliklere } \\
\text { Ayırarak Ekleme }\end{array}$ & $\begin{array}{c}\text { Üzerine } \\
\text { Sayma }\end{array}$ & $\begin{array}{c}\text { Sayıları Onu } \\
\text { Referans Alarak } \\
\text { Parçalama }\end{array}$ \\
\hline Tercihler & 14 & 17 & 2 \\
\hline
\end{tabular}

Tablo 3'e göre öğrencilerin çoğunun kullandıkları stratejilerle paralel olarak tercih ettikleri stratejilerin de birbirine yakın oranlarda "üzerine sayma" ve "onluklara ve birliklere ayırarak ekleme" stratejilerini tercih etmișlerdir. Buna göre öğrencilerin zihinden toplama ișlemi yaparken bu iki stratejiyi daha çok benimsedikleri tespit edilmiştir. Öğrenciler kullandıkları stratejilerin sıralamasından faklı olarak en çok zihinden toplama işlemi yaparken "üzerine sayma" stratejisini tercih etmiştir. Öğrencilerle yapılan mülakatlarda bu stratejinin seçilmesinin sebebinin bu stratejinin kolay ve kalıcı olması olduğunu belirtmişlerdir. Ö 6 kodlu öğrenci bunun gerekçesini "Bana daha kolay gelmişti hem de bunu daha çok anlamıştım. Diğer stratejileri bundan sonra anlamaya başladım" şeklinde açıklarken $\ddot{O}_{11}$ kodlu öğrenci bu durumun sebebini "Çünkü daha uzun ve beni uğraştırıyor. Uğraşmayı seviyorum" şeklinde ilginç bir şekilde belirtmiştir. Öte yandan öğrencilerin büyük bir bölümü de "onluklara ve birliklere ayırarak ekleme" stratejisini tercih etmiştir. Bu yöntemi tercih eden öğrencilerin çoğu bu stratejinin diğerlerine oranla daha kolay olduğunu ifade etmiştir. Öğrencilerle yapılan mülakatlarda Ö$_{15}$ kodlu öğrenci bunun gerekçesini "onluklara ve birliklere ayırarak toplamada üzerine saymaya göre daha az işlem harcanlyor. Zamandan daha fazla tasarruf elde ediliyor" şeklinde açıklarken $\ddot{O}_{25}$ kodlu öğrenci bu durumun sebebini "soruda her sayıyı onluğa ve birliğe ayırmak daha kolay" șeklinde yanıtlamıștır. Diğer yandan az sayıda öğrenci de "sayıları 10'u referans alarak parçalama" stratejisini tercih etmiştir. Öğrencilerle yapılan mülakatlar sonunda $\ddot{O}_{28}$ kodlu öğrenci bunun gerekçesini “...kendime daha uygun bulduğum için seçtim” șeklinde açılarken Ö$_{10}$ kodlu öğrenci bu durumun sebebini “...bana mantıklı geldiği için...” şeklinde açıklamıştır.

Birbirine yakın oranlarda da olsa öğrencilerin zihinden toplama işlemi yaparlarken en çok onluklara ve birliklere ayırarak toplama kullanmalarına rağmen yapılan zihinden toplama işlemlerinde en çok üzerine sayma stratejisini tercih etmeleri araştırmacıların dikkatini çekmiştir. Bu durumun sebebini ortaya çıkarmak için kullandıkları stratejiler ile tercih ettikleri stratejiler arasında farklılık bulunan öğrenciler ile birer görüșme daha yapılmıștır. Öğrencilere bu farklılığın nedeni sorulmuştur. Görüşmelerin sonucunda öğrencilerin kullandıkları stratejilerden farklı olsun gerekçesi ile tercih ettikleri stratejiyi değiștirdikleri ortaya çıkmıștır. Bu sebeple ortaya çıkan bu farklılığının önemsenmemesi gerektiğine karar verilmiştir. Așağıda zihinden toplama işlemi yaparken onluklara ve birliklere ayırarak toplama stratejisini yoğun olarak kullanan fakat üzerine sayma stratejisini tercih eden $\mathrm{O}_{7}$ kodlu öğrenci ile birinci yazar arasında geçen konuşmaya yer verilmiștir.

Araștırmacl: 43+29 işlemine yönelik zihinden toplama stratejileri arasinda hangi stratejiyi tercih etmiștin?

$\ddot{O}_{7}:$ Ben üzerine sayma stratejisini tercih etmistim.

Araștırmacı: Peki neden bu üzerine sayma stratejisini tercih ettin?

$\ddot{O}_{7:}$ Öğretmenim diğerleri benim kafamı karıștırıyor. Sayıları 10'u referans alarak parçalama kafamı çok karıştırıyor. O yüzden onu tercih etmedim.

Arasstırmacl: Peki onluklara ve birliklere ayırarak eklemeyi neden tercih etmedin?

$\ddot{O}_{7:}$ Öğretmenim o strateji benim o kadar kafamı karıștırmıyor da bana biraz zor gibi geliyor. $O$ yüzden üzerine saymayı tercih ettim.

Araştırmacl: Tercih ettiğin strateji olarak üzerine sayma stratejisini söylemişsin. Ancak ön tarafta $37+32$ toplama işlemini yaparken onluklara ve birliklere ayırarak ekleme stratejisini kullanmısssın. Burada neden üzerine sayma stratejisini kullanmadın?

$\ddot{O}_{7}$ : Aynılık olsun istemedim. 


\section{Zihinden Çıkarma İşlemi Yaparken Kullanılan Stratejiler}

Bu bölümde öğrencilerin zihinden çıkarma işlemi yaparken ne tür stratejiler kullandıklarını belirlemek amacıyla sorulan iki soruya (52-27, 68-31) yönelik verdikleri yanıtlar incelenmiștir. Öğrencilerin verdikleri yanıtların "Onlukları ve birlikleri ayırarak çıkarma”, "Onar onar eksiltme” ve "Strateji yok veya boş” olmak üzere toplam üç kategori altında toplandığı tespit edilmiştir. Tablo 4'te öğrencilerin bu kategorilere dağılımı hakkında bilgiler sunulmuştur.

Tablo 4. Zihinden Çıkarma İşlemi Yaparken Kullanılan Stratejiler

\begin{tabular}{lcccccc}
\hline \multicolumn{1}{c}{ Stratejiler } & 4.Soru & $\%$ & 5.Soru & $\%$ & TOPLAM & $\%$ \\
\hline Onlukları ve birlikleri ayırarak çıarma & 6 & 18 & 9 & 27 & 15 & 22 \\
Onar onar eksiltme & 13 & 39 & 8 & 24 & 21 & 32 \\
Strateji yok veya boş & 14 & 43 & 16 & 49 & 30 & 46 \\
TOPLAM & 33 & 100 & 33 & 100 & 66 & 100 \\
\hline
\end{tabular}

Tablo 4'e göre öğrencilerin yaklaşık yarısının zihinden çıkarma işlemi yaparlarken uygun bir strateji kullanamadıkları veya boş bıraktıkları belirlenmiștir. Bu durum öğrencilerin yaklaşık yarısının zihinden çıkarma işlemine yönelik bir strateji benimseyemedikleri şeklinde yorumlanabilir. Zihinden çıkarma işleminin sorulduğu hem birinci hem ikinci hem de toplamda öğrencilerin bu durumu değişmemiştir. Buna göre öğrencilerin çoğunun zihinden çıkarma stratejileriyle ilgili bilgi düzeylerinin yeterli olmadığı ya da bu stratejilerden herhangi birini de olsa özümsemedikleri söylenebilir. Bu öğrencilere örnek olması açısından $\ddot{O}_{21}$ kodlu öğrencinin birinci soruya ilişkin verdiği yanıt Şekil 5'te sunulmuştur.

Şekil 5. Herhangi Bir Zihinden Çıkarma Stratejisinin Kullanılmadığı Çözüm

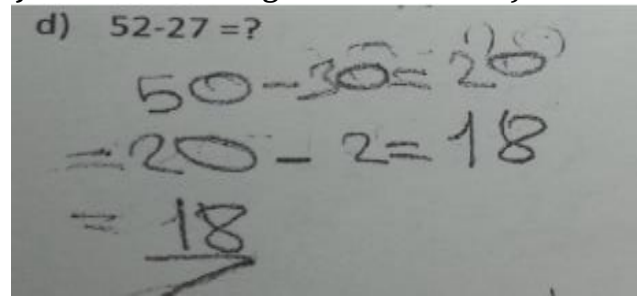

Şekil 5'e göre $\ddot{O}_{21}$ kodlu öğrenci birinci sorunun çözümü için herhangi bir strateji kullanamamış ve soruyu yanlış çözmüştür. Öğrenci burada eksilen ve çıkan sayıları en yakın onluğa yuvarladıktan sonra birbirinden çıkarmış ve bulduğu sonucu da iki sayı olduğu düşüncesiyle 2 sayısından çıkararak sonuca ulaşmıştır. Öğrenci yaptığı bu işlemlerin "onluklarla ve birliklerle eksiltme" stratejisine uygun olduğunu iddia etmiștir.

Zihinden çıkarma işlemi yaparken uygun strateji uygulayan öğrencilerin en çok onar onar eksiltme stratejisini kullandıkları tespit edilmiştir (\%32). Bu strateji zihinden çıkarma işleminin sorgulandığı birinci soruda en çok kullanılan yöntem iken ikinci soruda ise birbirine çok yakın oranlarda da olsa ikinci sırada kullanılan yöntem olmuştur. Birinci sorunun çözümünde onar onar eksiltme stratejisini kullanan $\ddot{O}_{7}$ kodlu öğrencinin yanıtı aşağıda Şekil 6'de gösterilmiştir. 
Şekil 6. Onar Onar Eksiltme Stratejisinin Kullanıldığı Çözüm

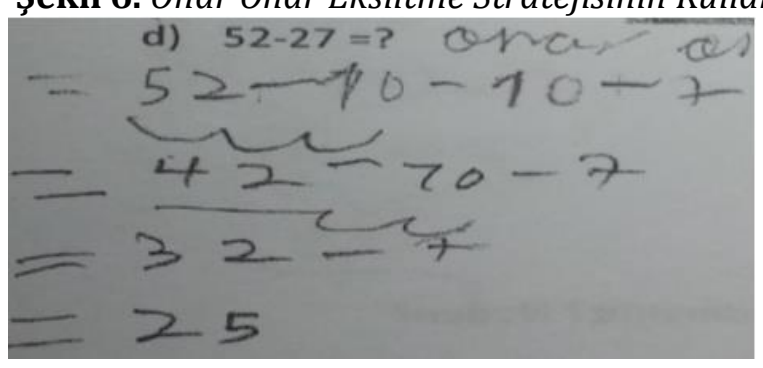

Şekil 6'ya göre Ö$_{7}$ kodlu öğrenci kullandığı stratejide çıkan sayı olan 27 sayısını ayırabildiği kadar onluğa ayırıp geriye de bir tane birliği temsil eden 7 sayısı kalacak şekilde sayıları çıkarılmak üzere yazmıștır. Daha sonra eksilen sayı olan 52 sayısını da onluklarla ve birlikle ikili ikili çıkarma işlemi yaparak 25 sonucuna ulaşmıştır.

Öğrencilerin zihinden çıkarma işlemi yaparken en son sırada kullandıkları strateji onlukları ve birlikleri ayırarak çlkarma stratejisi olmuștur (\%22). Bu strateji birinci soruda son sırada ikinci soruda ise az bir fark ile birinci sırada kullanılmıştır. Şekil 7'de bu stratejiyi ikinci sorunun çözümünde kullanan Ö 9 kodlu öğrencinin verdiği yanıta yer verilmiştir.

Şekil 7. Onlukları ve Birlikleri Ayırarak Çıkarma Stratejisinin Kullanıldı̆̆ı Çözüm

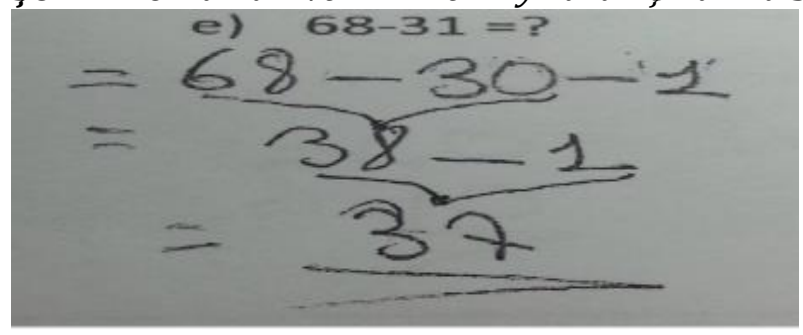

Şekil 7’ye göre Ög kodlu öğrenci kullandığı stratejide çıkan sayı olan 31 sayısını, 30 ve 1 sayılarının toplamı şeklinde yazarak sayıyı bir tane onluğa ve bir tane birliğe ayırmıştır. Daha sonra eksilen sayı olan 68 sayısıyla daha önce onluğa ve birliğe ayırdığı sayıları ikili ikili çıkarmış ve 37 sonucuna ulaşmıştır.

\section{Zihinden Çıkarma İşlemi Yaparken Tercih Edilen Stratejiler}

Öğrencilerin zihinden çıkarma işlemi yaparken benimsedikleri stratejiyi ortaya çıkarmak için hem destekleyici bulgular elde etmek hem de olası farklılıkları ortaya çıkarabilmek için öğrencilere bir çıkarma işleminin yapılmış iki farklı çözümü sunulmuştur. Soruda 43-29 işleminin onar onar eksiltme ve onluklara ve birliklere ayırarak çıkarma stratejileri ile yapılmış çözümü sunulmuş ve hangisini daha çok tercih edecekleri sorulmuştur. Elde edilen sonuçlara tablo 5 'te yer verilmiştir.

Tablo 5. Zihinden Çıkarma İșleminde Tercih Edilen Stratejiler

\begin{tabular}{lcc} 
Stratejiler & $\begin{array}{c}\text { Onlukları ve Birlikleri } \\
\text { Ayırarak Çıkarma }\end{array}$ & $\begin{array}{c}\text { Onar Onar } \\
\text { Eksiltme }\end{array}$ \\
\hline
\end{tabular}

Tercihler

15

18

Tablo 5'e göre öğrencilerin çoğu zihinden çıkarma işlemi yaparken kullandıkları stratejiler ile paralel olarak "Onar onar eksiltme" stratejisini daha çok tercih ettikleri belirlenmiştir (\%55). Buna göre öğrencilerin zihinden çıkarma ișlemi yaparken benimsedikleri stratejinin çoğunlukla onar onar eksiltme stratejisi olduğu söylenebilir. Öğrencilerle yapılan görüşmelerde bu stratejiyi kolay ve kısa olduğu için tercih ettiklerini ifade etmişlerdir. Örneğin mülakatlar sırasında Ö ${ }_{18}$ kodlu öğrenci 
tercih gerekçesini “...daha kısa sürüyor ve daha hesaplı..." şeklinde açıklarken $0_{5}$ kodlu öğrenci sebebini "çünkü kendimizi yormadan beynimizde tasarlayabiliyoruz" şeklinde belirtmiştir. Öte yandan öğrencilerin büyük bir bölümü de "onlukları ve birlikleri ayırarak çıkarma" stratejisini tercih etmiştir (\%45). Bu öğrenciler de onluk ve birliklere ayırarak çıkarma stratejisinin diğer stratejiye göre daha kolay olduğu için tercih ettiklerini belirtmişlerdir. Öğrencilerle yapılan mülakatlar sonunda Ö$_{29}$ kodlu öğrenci bunun gerekçesini "çünkü çıkarma işlemi karışmıyor ve daha kolay" şeklinde açıklarken Ö ${ }_{4}$ kodlu öğrenci bu durumun sebebini "çünkü bu şsekilde çıkarma işlemini daha güzel anllyorum bunda daha çok kavrıyorum" șeklinde yanıtlamıştır. Öğrenciler büyük çoğunlukla kullandıkları stratejiler ile tercih ettikleri stratejiler uyumludur. Araştırmada dikkat çeken bir durum öğrencilerin kullandıkları iki stratejinin birbirine göre oranlarının tercih edilen stratejilerde onluklara ve birlikleri ayırarak çıkarma lehine az da olsa artmasıdır. Bu durumun sebebini ortaya çıkarabilmek için zihinden çıkarma işlemi yaparken onar onar eksiltme stratejisini yoğun olarak kullanan fakat onluklara ve birlikleri ayırarak çıkarma stratejisini tercih eden öğrencilerde bu durumun sebebi sorgulanmıştır. Yapılan inceleme sonucunda öğrencilerin onar onar eksiltme stratejilerini benimsemelerine rağmen onlukları ve birlikleri ayırarak çıkarma stratejisini farklılık olsun düşüncesiyle tercih ettiklerini ifade etmişlerdir. Buna göre öğrencilerin asıl benimsedikleri stratejilerin kullandıkları stratejiler olduğunu belirtmek ve tercih ettikleri stratejilerin mantıklı argümanlara dayalı tercihler olmadığından bir anlam ifade etmediğini söylemek mümkündür. Aşağıda bu öğrencilerden biri olan Ö$_{6}$ kodlu öğrenci ile birinci yazar arasında geçen konuşmaya yer verilmiştir.

Araştırmacı: 43-29 işlemine yönelik zihinden çıkarma stratejileri arasında hangi stratejiyi tercih etmiștin?

$\ddot{O}_{6}:$ Onlukları ve birlikleri ayırarak çıkarma stratejisini tercih ettim.

Araștırmacı: Peki neden bu stratejiyi tercih ettin?

Ö$_{6}$ Çılkarmada bu stratejinin daha kolay olacağını düşündüm.

Araştırmacl: Onlukları ve birlikleri ayırarak çıkarma işlemini tercih ettiğini söyledin ancak sana sorulan sorularda daha çok onar onar çıkarma stratejisini kullanmışsın. Bunun bir sebebi var mı?

$\ddot{O}_{6:}$ Arka sayfada zihinden çıkarma stratejileri tercihleri arasında ilk onlukları ve birlikleri ayırarak çıkarma stratejisini gördüm. İlk bu stratejiyi gördüğümde daha önceden onar onar eksiltme stratejisini tekrar uygulamayayım diye onlukları ve birlikleri ayırarak çıkarma stratejisini işaretledim.

Araştırmacı: Açıklamak istediğin şeyleri biraz daha ayrıntılı anlatır mısın?

$\ddot{O}_{6:}$ Aslında onar onar eksiltme stratejisini daha çok kullanıyordum ama şimdi bir değişiklik olsun, biraz ikisini de anlamış görüneyim diye diğer stratejiyi seçtim.

\section{TARTIŞMA ve SONUÇ}

Ortaokul beşinci sınıf öğrencilerinin zihinden toplama işlemine yönelik üç açık uçlu soruya verdikleri cevaplar incelendiğinde, öğrencilerin toplama işlemi yaparken dört farklı zihinden hesaplama stratejisi kullandıkları görülmüştür. İki basamaklı iki sayının zihinden hesaplanmasının istendiği birinci ve ikinci açık uçlu sorular birlikte değerlendirildiğinde, öğrencilerin en fazla "onluklara ve birliklere ayırarak ekleme" stratejisini, daha sonra "üzerine sayma" stratejisini, en az ise "sayıları onu referans alarak parçalama" stratejisini kullandıkları tespit edilmiştir. Üç adet iki basamaklı sayının zihinden toplanılmasının istendiği üçüncü açık uçlu soruya verilen cevaplar incelendiğinde, öğrencilerin en fazla "kolay toplanan sayılardan başlama" stratejisini, daha sonra "onlukları ve birlikleri ayırarak ekleme" stratejisini, en az ise "üzerine sayma" stratejisini kullandıkları görülmüştür. Ayrıca çoğu öğrenci bu sorulardaki zihinden toplama işlemlerine yönelik herhangi bir stratejiyi doğru şekilde kullanmamış ya da bu sorulara cevap vermemiştir. Öğrencilerin zihinden çıkarma işlemi yaparken kullandıkları stratejileri belirlemeye yönelik yapılan çalışmada öğrencilerin en fazla "onar onar eksiltme" stratejisini, en az ise "onlukları ve birlikleri ayırarak çıkarma" stratejisini kullandıkları tespit edilmiştir. Bu sorularda da çoğu öğrencinin zihinden çıkarma işlemlerine yönelik herhangi bir stratejiyi doğru şekilde kullanmadığı ya da bu sorulara cevap vermediği belirlenmiştir. 
Çalışmada öğrencilerin büyük çoğunluğunun zihinden toplama ve çıkarma işlemi yaparken uygun stratejileri kullanamamaları ve zihinden hesaplamalar yapamayarak soruları boş bırakmaları öğrencilerin bu stratejilere yönelik güçlük yaşadıklarını ortaya çıkarmıştır. Çoğu öğrencinin zihinden toplama-çıkarma işlemlerine yönelik herhangi bir stratejiyi doğru kullanmamış ya da cevap vermemiş olmasının nedeni öğrencilerin stratejileri uygularken sayı duygusunu kaybetmelerinden (Beishuizen, 2001; Heirdsfield \& Cooper, 2004a) kaynaklanıyor olabilir. Öğrencilerin sahip oldukları güçlükler öğrencilere bu konuda verilen eğitimin yeterli olup olmadığı sorusunu da akla getirmiştir. Öğrencilerin zihinden rahat bir şekilde hesaplama yapabilmeleri adına gerekli çalışmalar yapılmalıdır. Dersin öğretiminden sorumlu öğretmenlerin ders işleniş yöntemlerini tekrar gözden geçirmelerinde fayda vardır. Unutulmamalıdır ki, zihinden hesaplama yapmak sadece matematik derslerini rahat bir şekilde anlaşılmasına yardımcı olmanın yanında bireyin günlük hayatını da kolaylaştıracak, hesaplamalarla ilgili birçok günlük hayat problemlerinin hızlı bir şekilde çözmelerine yardımcı olacaktır. Bu bakımdan öğrencilerin zihinden hızlı bir şekilde hesaplama yapmaları önemsenmelidir. Çünkü zihinden hesaplama yapmak sadece matematik dersi ile ilgili değil bizzat hayatın kendisi ile ilgilidir.

Görüşme formunun ikinci bölümünde öğrencilerin zihinden toplama ve çıkarma işlemleri yaparken benimsedikleri stratejileri teyit etmek için öğrencilere farklı stratejiler kullanılarak yapılan zihinden toplama ve çıkarma işlemlerini değerlendirmeleri istenmiştir. Yapılan çözümlerde kullanılan stratejilerden hangisini tercih ettikleri sorulmuştur. Yapılan değerlendirmeler sonucunda öğrencilerin kullandıkları stratejiler ile tercih ettikleri stratejilerin büyük oranda örtüştügü ortaya çıkmıştır. Kullandıkları stratejiler ile tercih ettikleri stratejiler arasında farklılık olan öğrencilerle görüşülmüştür. Yapılan görüşmelerin sonucunda bu öğrencilerin tercih ettikleri stratejilerde bilinçli bir seçim yapmadıkları, kullandıkları strateji ile farklılık olması için tercihlerini gerçekte kullandıkları stratejilerden yana kullanmadıkları ortaya çıkmıştır. Bu nedenle öğrencilerin gerçekten benimsedikleri stratejinin işlemleri yaparken kullandıkları stratejiler olduğu ortaya çıkmıştır.

Çalışmada öğrencilerin zihinden toplama ișlemi yaparken kullandıkları stratejilere yönelik elde edilen sonuçlar literatürde yer alan bazı çalışmalarla paralellik göstermiştir. Blote, Klein ve Beishuizen'in (2000) ilkokul ikinci sınıfta öğrenim gören Hollandalı öğrencilerin zihinden hesaplama yaparken en çok "onluklarına ve birliklerine ayırarak ekleme" stratejisini kullandıkları tespit etmiştir. Yine Hollanda'da ilkokul üçüncü sınıfta öğrenim gören öğrencilerle yapılan bir durum çalışmasında öğrencilerin zihinden hesaplama yaparken baskın olarak kullandıkları stratejilerin ayrıştırıcı ve birleștirici soldan sağa stratejisi olarak isimlendirilen "onluklarına ve birliklerine ayırarak ekleme” stratejisi olduğu görülmüștür (Ruesink \& Van den Heuvel-Panhuizen, 1991). Resnick (1986) tarafından yedi yaş grubu ilkokul öğrencileri üzerinde yapılan durum çalışmasında öğrenciler toplama işlemleri yaparken en fazla soldan sağa olarak ifade edilen "onluklarına ve birliklerine ayırarak ekleme" stratejisiyle yuvarlama yapmayı gerektiren "dengeleme" stratejisini kullanmıștır. Bununla birlikte Amerika'da ve Avrupa'da ilkokul düzeyinde öğrenim gören öğrencilerin toplama işlemi yaparken en fazla kullandıkları zihinden hesaplama stratejisinin "onluklarına ve birliklerine ayırarak ekleme" stratejisi olduğu ve bu stratejinin öğrenme ortamlarındaki kullanımının teşvik edildiği belirtilmiștir (Heirdsfield \& Cooper, 2004b; Klein \& Beishuizen, 1994). Öte yandan bu araştırmada öğrencilerin zihinden toplama işlemi yaparken en az "sayıları onu referans alarak parçalama" stratejisini kullandıkları şeklindeki bulgu, literatürde bulunan bazı araştırmalardan elde edilen sonuçlarla çelişmiştir (Carpenter, Franke, Jacobs, Fennema, \& Empson, 1998; De Corte \& Verschaffel, 1987; Heirdsfield \& Cooper, 1996). Nitekim Morais ve Serrazina (2013) tarafından yapılan çalışmada karşılaștırma ve tamamlama problemlerinde toplama işlemi yaparken kullanılan zihinden hesaplama stratejisi "sayıları onu referans alarak parçalama" olmuştur. Bu araștırmada öğrencilerin zihinden toplama işlemi yaparken "onluklarına ve birliklerine ayırarak ekleme" stratejisini diğer stratejilere oranla daha fazla kullanmalarının nedeni ilkokul matematik derslerinde çoğu zaman birlik ve onluk bloklar yardımıyla yapılan etkinliklerden (Nelissen, 1980; Buys, Teunissen \& Van Bergen, 1981) kaynaklı olabilir. Nitekim öğrenciler bu blokları kullanarak sayıları onluklarına ve birliklerine ayırma işleminde beceri kazandığından gelecekte karşılarına çıkan hesaplama problemlerinde de aynı stratejiyi kullanıp zorlanmadan sonuca ulaşabilirler. Öğrencilerin "üzerine sayma" stratejisini bu stratejiden daha az kullanmasının 
nedeni ise öğrencilerin mülakatlarda belirttikleri gibi üzerine sayma stratejisinin daha zaman alıcı olmasindan kaynaklanabilir.

Çalışmada öğrencilerin zihinden çıkarma işlemi yaparken kullandıkları stratejilere yönelik elde edilen sonuçlar literatürde yer alan bazı çalışmalarla paralellik göstermiştir. İlkokul öğrencilerinin zihinden çıkarma işlemi yaparken "onlukları ve birlikleri ayırarak çıkarma" stratejisini baskın şekilde kullandıkları (Beishuizen, Wolters, \& Broers, 1991; Blote et al., 2000; Van Mulken, 1992) bulgusu araştırmanın bu bölümünden elde edilen bulgularla tutarlılık göstermiştir. Ancak literatürde araştırmanın bu bölümünden elde edilen bulgulardan daha farklı bulguların da olduğu tespit edilmiştir. Bu bağlamda, Avrupa'da ilkokul birinci ve üçüncü sınıflarında öğrenim gören öğrencilerin çıkarma işlemi yaparken onlukları ve birlikleri ayırarak çıkarma stratejisine benzer nitelikte ve soldan sağa olarak isimlendirdikleri zihinden hesaplama stratejisini kullandıkları görülmüştür (Carraher et al., 1987; Morais \& Serrazina, 2013; Resnick, 1986). Söz konusu stratejide öğrenciler birliklerin ve onlukların kendi arasında farklarını aldıktan sonra kalan sayıları toplayarak sonuca ulaşmaktadır. Bu araştırmada öğrencilerin çıkarma işlemi yaparken "onar onar eksiltme" isimli zihinden hesaplama stratejisini diğer stratejiye oranla daha fazla kullanmasının nedeni çıkarma işleminde eksilen sayıyı çıkan sayıdan onar onar çıkartılarak sonuca adım adım gitmenin daha güvenilir işlem basamakları şeklinde yorumlanması olabilir. Öğrencilerin "onlukları ve birlikleri ayırarak çıkarma" stratejisini daha az kullanmasının nedeni ise birlik ve onluk sayma bloklarıyla yapılan çıkarma işlemlerinin, toplama işlemlerinin aksine daha karıșık ve hataya yönlendirebilecek bir özellikte olduğu algısı olabilir. Çünkü bu stratejide birbirinden çıkarılan sayılar on ve onun katları şeklinde olmayacağı için öğrenciyi devamlı işlem yapmaya zorlayıp kolay çıkarma özelliğini ortadan kaldırabilecektir.

$\mathrm{Bu}$ çalışma nitel araştırma yaklaşımı esas alınarak bir devlet ortaokulunun beşinci sınıflarında öğrenim gören 33 öğrenciyle gerçekleştirilmiştir. Benzer çalışmalar farklı araştırma grupları ile literatürde mevcut olan çeşitli zihinden hesaplama stratejileri dikkate alınarak tekrarlanabilir. Öğrenciler tarafından toplama ve çıkarma işlemlerinde hiç kullanılmayan ya da daha az kullanılan zihinden hesaplama stratejilerinin neden kullanılmadıkları ya da neden daha az kullanıldıkları derinlemesine araştırılabilir. Son olarak yapılacak nitel araștırmalarda ortaokul öğrencilerinin toplama-çıkarma işlemleri yaparken kullandıkları zihinden hesaplama stratejilerini sayı doğrusu üzerinde görsel olarak da göstermeleri istenebilir. Zihinden hesaplama ile sayı duygusu arasındaki sıkı ilişki (Heirdsfield, 2001) bilindiğinden matematik derslerinde öğrencilerin sayı duygularını arttıracak sınıf içi etkinliklerin yapılması öğrencilerin daha fazla zihinden hesaplama stratejileri kullanımını sağlayabilir. Bu sayede öğrenciler hem hesap makinesi kullanımı hem de parmak yoluyla sayma gibi davranışları daha az sergileyebilir. Öğrencilere zihinden hesaplama stratejilerini kullanabilecekleri ve yeni zihinden hesaplama stratejileri geliştirebilecekleri öğrenme ortamları sağlanmalıdır. Çünkü daha çabuk sonuca ulaştıran, daha kullanışlı ve pratik zihinden hesaplama stratejilerini kullanmak matematik dersindeki başarıyı etkilemektedir (Pesen, 2004).

\section{KAYNAKÇA}

Australian Education Council. (1991). A national statement on mathematics for Australian schools. Melbourne: Curriculum Corporation.

Baroody, A.J. (2006). Why children have difficulties mastering the basic number combinations and how to help them. Teaching Children Mathematics, 13(1), 22-31.

Beishuizen, M. (2001). Different approaches to mastering mental calculation strategies. In J. Anghileri (Ed.), Principles and Practices in Arithmetic Teaching-Innovative Approaches for the Primary Classroom (pp. 119-130). Buckingham: Open University Press.

Beishuizen, M. (1993). Mental strategies and materials or models for addition and subtraction up to 100 in Dutch second grades. Journal for Research in Mathematics Education, 24(4), 294-323.

Beishuizen, M., Wolters, G., \& Broers, G. (1991). Research into mental computation procedures in the number domain 20-100 using response times and speed tests. Tijdschrift voor Onderwijsresearch, 16, 19-38.

Blote, A.W., Klein, A.S., \& Beishuizen, M. (2000). Mental computation and conceptual understanding. Learning and Instruction, 10, 221-247. 
Buys, K. (2008). Mental arithmetic. In M. van den Heuvel-Panhuizen (Ed.), Children learn mathematics: A learning-teaching trajectory with intermediate attainment targets for calculation with whole numbers in primary school (pp. 121-146) Netherlands: Sense Publishers.

Buys, N., Teunissen, F., \& Van Bergen, T. (1981). Teachers' manual "operatoir rekenen": 2nd grade. Tilburg, The Netherlands: Zwijsen.

Carpenter, T.P., Franke, M.L., Jacobs, V.R., Fennema, E., \& Empson, S.B. (1998). A longitudinal study of invention and understanding in children's multidigit addition and subtraction. Journal of Research in Mathematics Education, 29(1), 3-20.

Carraher, T.N., Carraher, D.W., \& Schliemann, A.D. (1987). Written and oral mathematics. Journal for Research in Mathematics Education, 18, 83-97.

Ceylan, S., \& Özdemir, A.Ş. (2012). Nihayetul-elbab adlı eserde kullanılan zihinden hesap yöntemlerinin 6.sinıf ögrencilerinin zihinden hesap ve tahmin becerilerine etkisi. X. Ulusal Fen Bilimleri ve Matematik Eğitimi Kongresi, Niğde Üniversitesi, Niğde, Türkiye.

Cooper, T.J., Heirdsfield, A., \& Irons, C. (1995). Year 2 and 3 children's strategies for mental addition and subtraction. In B. Atweh \& S. Flavel (Eds.), GALTHA (pp. 195-202). Darwin: MERGA Inc.

Creswell, J.W. (2013). Qualitative inquiry and research design: Choosing among five traditions (3rd Ed.). California: Sage Publication.

Çavuş Erdem, Z., \& Duran, H. (2015). Yetişkinlerin zihinden hesaplama becerilerinin özellikleri üzerine karşılaştırmalı bir çalıșma. Türk Bilgisayar ve Matematik Eğitimi Dergisi, 6(3), 463-482.

De Corte, E., \& Verschaffel, L. (1987). The effect of semantic structure on first graders' strategies for solving addition and subtraction word problems. Journal for Research in Mathematics Education, 18(5), 363-381.

Department of Education and Science. (1987). Mathematics from 5-16 (2nd Ed.). London: Curriculum Matters 3AN HMT Series.

Glesne, C. (2013). Nitel araştırmaya giriş (2.Basım) (Çev. A. Ersoy \& P. Yalçınoğlu). Ankara: Anı Yayıncllık.

Heirdsfield, A. (2002). Inaccurate mental addition and subtraction: Causes and compensation. In B. Barton, K.C. Irwin, M. Pfannkuch \& M.O.J. Thomas (Eds.), Mathematics education in the south pasific (pp. 334-341). Auckland: MERGA Inc.

Heirdsfield, A. (2001). Integration and compensation in accurate mental computation. In J. Bobis, B. Perry \& M. Mitchelmore (Eds.), Numeracy and beyond (pp. 273-280). Sydney: MERGA Inc.

Heirdsfield, A., \& Cooper, T.J. (2004a). Factors affecting the process of proficient mental addition and subtraction: Case studies of flexible and inflexible computers. Journal of Mathematical Behavior, 23, 443463.

Heirdsfield, A., \& Cooper, T.J. (2004b). Inaccurate mental addition and subtraction: Causes and compensation. Focus on Learning Problems in Mathematics, 26(3), 43-66.

Heirdsfield, A., \& Cooper, T.J. (1996). The "ups" and "downs" of substraction: Young children's additive and subtractive mental strategies for solutions of subtraction word problems and algorithmic exercises. In P. Clarkson (Ed.), Technology in mathematics education (pp. 261-268). Melbourne: MERGA Inc.

Henry, V., \& Brown, R. (2008). First-grade basic facts. Journal for Research in Mathematics Education, 39, 153183.

Karasar, N. (2005). Bilimsel araştırma yöntemi. Ankara: Nobel Yayın Dağıtım.

Klein, T., \& Beishuizen, M. (1994). Assessment of flexibility in mental arithmetic. In J.E.H. LuitVan (Ed.), Research on learning and instruction in kindergarten and primary school (pp. 125-152). Doetinchem, The Netherlands: Graviatt Publishing Company.

Lincoln, Y.S., \& Guba, E.G. (1985). Naturalistic inquiry. California: Sage Publication.

McIntosh, A., \& Dole, S. (2000). Mental computation, number sense and general mathematics ability: Are they linked?. In J. Bana \& A. Chapman (Eds.), Mathematics education beyond 2000 (pp. 401-408). Perth: MERGA Inc.

Merriam, S. (2013). Nitel araştırma-desen ve uygulama için bir rehber (Çev. S. Turan). Ankara: Nobel Yayınevi.

Miles, B.M., \& Huberman, M.A. (1994). Qualitative data analysis. London: Sage Publication.

Morais, C., \& Serrazina, L. (2013). Mental computation strategies in subtraction problem solving. In B. Ubuz (Ed.), CERME 8 (pp. 333-342), Ankara: Middle East of Technical University.

MEB (Milli Eğitim Bakanlığı). (2015). Ortaokul matematik 5.sınıf ders kitabı. Ankara: Özgün Matbaacılık.

MEB (Milli Eğitim Bakanlı̆̆ı). (2014). Ortaokul matematik 5.sınıf ders kitabı. Ankara: Pasifik Yayınları.

MEB (Milli Eğitim Bakanlı̆̆ı). (2009). İlköğretim matematik dersi 6-8.sınıflar öğretim programı. Ankara: Milli Eğitim Basımevi.

National Curriculum for England. (1999). Mathematics. Department of Education and Employment, London: Qualifications and Curriculum Authority.

Nelissen, J. (1980). The theory of gal'perin in discussion. Pedagogische Studien, 57, 305-321. 
NCTM (National Council of Teachers of Mathematics). (2000). Principles and standards for school mathematics. Reston: NCTM Publishing.

Pesen, C. (2004). Zihinden toplama ve çıkarma işlemlerinde kullanılan yöntemlerin ilköğretim 1.sınıf öğrencilerinin başarı düzeyine etkisi. Ege Eğitim Dergisi, 5, 17-23.

Piaget, J. (1976). The psychology and intelligence in children. New York: International Universities Press.

Resnick, L.B. (1986). The development of mathematical intuition. In M. Parlmutter (Ed.), Perspectives on intellectual development: The minnesota symposium on child development (pp. 159-194). Hillsdale, NJ: Erlbaum.

Reys, R.E. (1984). Mental computation and estimation: Past, present and future. Elementary School Journal, 84(5), 546-557.

Reys, B.J., \& Barger, R.H. (1994). Mental computation: Issues from united states perspectives. In R.E. Reys \& N. Nohda (Eds.), Computational alternatives for the twenty-first century (pp. 31-47). Reston: NTCM Publishing.

Reys, R.E., Reys, B.J., Nohda, N., \& Emori, H. (1995). Mental computation performance and strategy use of japanese students in grades 2, 4, 6 and 8. Journal for Research in Mathematics Education, 26(4), 304-326.

Rubenstein, N. (2001). Mental mathematics beyond the middle school. Mathematics Teacher, 94(6), 442-447.

Ruesink, N., \& Heuvel-Panhuizen, M.V.D. (1991). Use of strategies with a number problem end of third grade. Panamapost, 9, 15-25.

Saxe, G.B. (1988). The mathematics of child street vendors. Child Development, 1415-1425.

Sowder, J.T. (1990). Mental computation and number sense. The Arithmetic Teacher, 37(7), 18-20.

Sowder, J.T. (1988). Making sense of numbers in school mathematics. In G. Leinhardt, R. Putman \& R. Hattrup (Eds.), Analysis of arithmetic for mathematics, Hillsdale, NJ: Erlbaum.

Trafton, P.R. (1978). Estimation and mental arithmetic: Important components of computation. In M. Suydam \& R.E. Reys (Eds.), Developing computational skills (pp. 196-213). Reston: NCTM Publishing.

Treffers, A., \& De Moor, E. (1990). Towards a national mathematics curriculum for the elementary school. Part 2: Basic skills and written computation. Zwijssen, Tilburg, The Netherlands.

Van de Walle, J.A. (1994). Elementary school mathematics: Teaching developmentally. New York: Longman.

Van de Walle, J.A., Karp, K., \& Bay-Williams, J. (2014). Elementary and middle school mathematics teaching developmentally ( $8^{\text {th }}$ Ed.). Essex, England: Pearson.

Van Mulken, F. (1992). Mental arithmetic and strategic action-two basic forms of addition and subtraction up to hundred. Unpublished doctoral dissertation, Leiden University, Leiden, The Netherlands.

Wyatt, J.W. (1985). A case-study survey of computational estimation processes and notions of reasonableness among ninth grade students. Unpublished Doctoral Dissertation, University of Missouri, Columbia, USA.

Willis, S. (1990). Numeracy and society: The shifting ground. In S. Willis (Ed.), Being numerate: What counts? (pp. 1-23). Melbourne: ACER.

Yazgan, Y., \& Bintaş, J. (2005). İlköğretim dördüncü ve beşinci sınıf öğrencilerinin problem çözme stratejilerini kullanabilme düzeyleri: Bir öğretim deneyi. Hacettepe Üniversitesi Eğitim Fakültesi Dergisi, 28, 210-218.

Yazgan, Y., Bintaş, J., \& Altun, M. (2002). İlköğretim beşinci sınıf öğrencilerinin zihinden hesap ve tahmin becerilerinin geliştirilmesi. V. Ulusal Fen Bilimleri ve Matematik Eğitimi Kongresi, Orta Doğu Teknik Üniversitesi, Ankara, Türkiye.

Yıldırım, A., \& Şimşek, H. (2008). Sosyal bilimlerde nitel araştırma yöntemleri (6.Basım). Ankara: Seçkin Yayıncilik. 


\section{EK-1. Etkinlik Temelli Yarı Yapılandırılmış Görüşme Formu}

Aşağıdaki işlemleri zihninizden yapınız. Bu işlemleri zihninizden toplarken ya da çıkarırken hangi stratejileri kullandığınızı açıklayınız.
a) $43+28=$ ?
b) $37+32=$ ?
c) $14+21+26=$ ?
d) $52-27=$ ?
e) $68-31=$ ?

43+29 = ? İşleminin sonucuna yönelik aşağıda toplama stratejileri yer almaktadır.

a) $43+29=43+20+9$ (Onluklara ve Birliklere Ayırarak Ekleme)

$$
\begin{aligned}
& =63+9 \\
& =72
\end{aligned}
$$

b) $43+29=43+10+10+9$ (Üzerine Sayma)

$$
\begin{aligned}
& =53+10+9 \\
& =63+9 \\
& =72
\end{aligned}
$$

c) $43+29=43+7+22$ (Onu Referans Alarak Parçalama)

$$
=50+22
$$

$=72$

SORU: Yukarıda verilen toplama stratejilerinden hangisini tercih edersiniz? Neden?

43-29 = ? İşleminin sonucuna yönelik aşağıda çıkarma stratejileri yer almaktadır.
d) $43-29=43-20-9$ (Onlukları ve Birlikleri Ayırarak Çıkarma)

$$
=23-9
$$$$
=14
$$

e) $43-29=43-10-10-9$ (Onar onar eksiltme)

$$
\begin{aligned}
& =33-10-9 \\
& =23-9 \\
& =14
\end{aligned}
$$

SORU: Yukarıda verilen çıkarma stratejilerinden hangisini tercih edersiniz? Neden? 